\title{
Every Book You Take: Evaluating Compliance Behavior in an Information Commons
}

\author{
Matheus Albergaria ${ }^{1}$
}

\begin{abstract}
There has been a heated debate related to the effects of business background on ethical behavior. According to some authors, students majoring in business courses - such as accounting, economics, and management - would be more likely to free ride or defect from coalitions in collective action situations, given the emphasis of such courses on individualistic values. Other authors have challenged that view, presenting empirical evidence that questions the link between business education and opportunistic behavior. The present paper revisits this debate, by studying the impact of business education on rule compliance in a specific type of information commons (libraries). Employing a novel dataset related to more than 700,000 library transactions during a 10-year period (2006-2015), I correlate business background with users' compliance behavior, while controlling for their time-invariant characteristics. I find no evidence of a significant effect of business education on rule compliance in this specific setting. In fact, some of the estimates here reported suggest a negative correlation between business background and compliance behavior. These results have important implications for ethical theories in economics, suggesting that compliance behavior is context-dependent.
\end{abstract}

\section{Keywords}

Business ethics. Economists' behavior. Information Commons. Organizational behavior. Rule compliance.

\section{Resumo}

Nos últimos anos, tem ocorrido um acalorado debate relacionado aos efeitos da formação na área de negócios sobre o comportamento ético. Segundo alguns autores, alunos formados em

- I thank the Editor, Dante Mendes Aldrighi, as well as three anonymous referees, for detailed comments and suggestions that greatly improved the paper. I also thank the comments from Fernando Postali, GilbertoTadeu Lima, Gílson Geraldino Jr., Ivam Ricardo Peleias, Marcos Poplawski-Ribeiro, Maria Sylvia Saes, Vitor Nasu, and seminar participants at the $25^{\text {th }}$ Annual Conference of the Society for Institutional and Organizational Economics (SIOE), Fundação Getúlio Vargas (FGV), and Universidade de São Paulo (USP). All remaining errors are my own.

1 Professor of Economics - Fundação Escola de Comércio Álvares Penteado (FECAP) Endereço: Avenida da Liberdade, 532 - Liberdade - São Paulo - SP - CEP: 01502-001 - Brasil. E-mail:matheus.magalhaes@fecap.br - ORCID: https://orcid.org/0000-0003-2788-1269. Recebido: 12/05/2020. Aceito: 02/08/2021. Editor Responsável: Dante Mendes Aldrighi

(c) (i) (\$) Esta obra está licenciada com uma Licença Creative Commons Atribuição-Não Comercial 4.0 Internacional. 
cursos da área de negócios - como administração de empresas, ciências contábeis e ciências econômicas - estariam, em princípio, mais propensos a pegar carona ou se desviar de coalizões em situações de ação coletiva, dada a ênfase desses cursos em valores individualistas. Outros autores contestaram essa visão, apresentando evidências empíricas que questionam a ligação entre formação em negócios e comportamentos oportunistas. O presente artigo revisita esse debate, estudando o impacto da formação acadêmica na área de negócios sobre o cumprimento de regras em um tipo específico de information commons (bibliotecas). Empregando uma nova base de dados, relacionada a mais de 700.000 transações de bibliotecas ocorridas durante um período de dez anos (2006-2015), a pesquisa busca correlacionar a formação em negócios com o comportamento de conformidade dos usuários, controlando para características invariantes no tempo. Em termos de resultados, não são encontradas evidências de um efeito significativo da formação em negócios sobre o cumprimento de regras nesse contexto específico. De fato, algumas das estimativas econométricas relatadas sugerem uma correlação negativa entre esse tipo de formação e comportamentos de conformidade. Os resultados reportados neste artigo têm importantes implicações para teorias éticas em economia, sugerindo que comportamentos de conformidade dependem do contexto considerado.

\section{Palavras-chave}

Ética empresarial. Comportamento de economistas. Information Commons. Comportamento organizacional. Cumprimento de regras.

\section{JEL Classification}

A12, A13, Z13.

\section{Introduction}

"Books are the best things, well used: abused, among the worst." - Ralph Waldo Emerson, American Scholar, 1837

During the last decades, some authors emphasized the individualistic approach followed by economists and business students. In particular, there is the possibility that undergraduates who major in business would be more likely to free ride or defect from coalitions in collective action situations (Carter and Irons 1991; Frank, Gilovich and Regan 1993; Marwell and Ames 1981). One implication of this line of reasoning is that studying economics may affect cooperation, or ethical behavior, broadly defined (Ruske 2015; Frey and Meier 2003; 2005). On the other hand, contributions published since the mid-nineties have challenged that view, presen- 
ting empirical evidence that questions the link between business education and opportunistic behavior (Delis, Hasan and Iosifidi 2019; Godos-Díez, Fernández-Gago and Cabeza-García 2015; Frey and Meier 2003, 2005; Meier and Frey 2004; Yezer, Goldfarb and Poppen 1996).

The present paper revisits this debate, by evaluating the impacts of business education on compliance behavior in a specific type of common-pool resource, an information commons (Rosen and Carr 1997; Hess and Ostrom 2007a; 2007b). I study the behavior of library users covering more than 700,000 transactions during a 10-year period. Specifically, I have access to confidential daily data related to library users of a private university in São Paulo, Brazil, containing detailed information on 16,232 individual users, covering 723,171 daily transactions for the 2006-2015 period.

The observational data used in this paper presents three advantages for testing the effects of a business education on behavior, when compared to previous contributions. The first advantage relates to its longitudinal aspect: since I am able to follow individual users across time, I present econometric estimations in which I can control for their time-invariant characteristics (fixed effects), an important source of non-observable bias in some settings, as suggested by previous research (Delis, Hasan and Iosifidi 2019). The second advantage refers to the possibility of contrasting the behavior of business students to a broader group of students, when compared to previous studies which focused on specific groups (Cadsby and Maynes 1998; Frank, Gilovich and Regan 1993; Yezer, Goldfarb and Poppen 1996). Finally, the third advantage corresponds to the possibility of tracking the behavior of distinct categories of library users (students, professors, and employees) over time, an advantage in terms of external validity, given the usual criticisms on laboratory experiments based exclusively on student subjects (Fréchette 2015; Kagel 2009).

Libraries arguably constitute an ideal setting for studying rule compliance, since they clearly establish specific return dates for items checked out by users, and send electronic reminders before (and after) they are due back (Apesteguia, Funk and Iriberri 2013). The existence of a number of variables related to library loans - such as dates of devolution, and number of books per user - allows me to build simple performance measures to evaluate compliance in this setting, such as frequency of delays, and the number of books borrowed by individual users, for example (more details below). Additionally, given the nature of the data, I am able to track users 
according to their personal information, such as identification number, university category (high school, undergraduate, master's, MBA, former student, professor, and employee), and area of study (management, accounting, economics, international relations, advertising, and secretariat). These features of the data allow me to explore distinct combinations of background and user category, while not being limited to student behavior.

The main result of the paper is the following: when estimating the effects of business background on compliance behavior in libraries, I cannot find a significant effect in this specific setting. That is, library users with a business background - such as accounting, economics, or management - do not present statistically significant differences when compared to users with other backgrounds. In fact, the results of some econometric estimations suggest a negative correlation between business background and compliance behavior. The paper's main result is robust to several specification issues, such as sample definitions, estimation techniques, and selection bias. This result is in line with recent contributions in business ethics that question the influence of business education on individual orientations and political views (Godos-Díez, Fernández-Gago and Cabeza-García 2015; Delis, Hasan and Iosifidi 2019). More than that, it has important implications for diverse areas, such as political economy (Beach and Jones 2016; Ruske 2015), the role of culture (Alesina and Giuliano 2015; Henrich et al. 2001), and social norms (Acemoglu and Jackson 2017; Bénabou and Tirole 2011; Fisman and Miguel 2007) in economic settings, as well as ethical theories of management (Melé 2009; Surprenant 2017; Arrkan 2018), for example. The results reported in this paper suggest that compliance behavior is a hypothesis that is context-dependent, and may need to be reformulated in some occasions.

The remainder of the paper proceeds as follows. Section 2 presents a selective description of the related literature, as well as its relation to the contributions in this paper. Section 3 describes the institutional setting under study, while section 4 describes the data and research design employed in the empirical analysis. Section 5 contains the paper's main results, as well as several related robustness checks. Finally, section 6 concludes. 


\section{Related Literature}

In this section, I discuss some of the contributions related to the debate regarding the influence of business background on behavior. In doing so, I have two goals: (i) to highlight this paper's specific contributions to distinct literatures, and (ii) to motivate the main hypotheses under test in the empirical section of the paper.

\section{Contributions}

This paper brings four main contributions to distinct literatures. First, the results here reported relate to a sparse set of contributions focused on the behavior of economists in laboratory and field settings (Carter and Irons 1991; Frank, Gilovich and Regan 1993; Yezer, Goldfarb and Poppen 1996; Marwell and Ames 1981). While the latter contributions focus on the sole behavior of economists, the present paper evaluates the interactions of library users from distinct areas of knowledge, such as management, accounting, international relations, advertising, and secretariat, following recent contributions that relate the effects of a business education on observed behavior (Delis, Hasan and Iosifidi 2019; Godos-Díez, FernándezGago and Cabeza-García 2015). These results contribute to the literature by contextualizing economists' behavior in a naturally occurring situation, when compared to other areas (Bauman and Rose 2011; Cadsby and Maynes 1998; Fosgaard, Fosgaard, and Foss 2017; Frey and Meier 2003, 2005; Meier and Frey 2004; Rubinstein 2006). By emphasizing differences based on area of expertise, the results in this paper contribute to a better understanding of the effects of specific social factors - such as identity, culture, and social norms - on observed behavior (Alesina and Giuliano 2015; Akerlof and Kranton 2005; 2000; Henrich et al. 2001; Acemoglu and Jackson 2017; Bénabou and Tirole 2011; Benjamin, Choi, and Fisher 2016). ${ }^{1}$

Second, given that library users may face sanctions for late items in the libraries under study, the results here presented dialogue with the economic literature on crime, and its applications (Becker, 1968; Chalfin and McCrary, 2017; Polinsky and Shavell, 2000). An important discussion in the field of law and economics relates to the merits of alternative ways to

1 I employ the term "naturally occurring situation" in this paper to distinguish the present setting from laboratory and field experiments's settings. See Frey and Meier (2003, 2004, 2005), and Meier and Frey (2004) for examples of similar use of the term. 
deter illicit behavior. The classical economic model of crime predicts that either monetary sanctions - such as fines - or non-monetary sanctions such as imprisonment - can work as a deterrence factor for illicit activities (Becker, 1968; Stigler, 1974). While most contributions in the economics literature focused on the deterrent effects of imprisonment, the tradeoff among distinct types of punishment has received far less attention (Piehl and Williams 2011). Discussions comparing fines to imprisonment suggest that, under certain conditions, the former may be preferred over the latter, especially in terms of economic efficiency, since they correspond to mere transfers of money across society (Polinsky and Shavell 2000). ${ }^{2}$

Third, when comparing the behavior of users subject to different kinds of sanctions (monetary and non-monetary), the present paper adds to a transdisciplinary literature on theimportance of distinct types of incentives. In fact, there is not a clear consensus among social scientists in terms of the superiority of monetary sanctions over other forms of punishment (Gneezy, Meier, and Rey-Biel 2011; Kamenica 2012; Surprenant 2017). Although there exists some evidence from laboratory experiments suggesting that different types of sanctions can affect behavior through distinct channels (Fehr and Gächter, 2000; Masclet, Noussair, Tucker and Villeval, 2003), the available evidence presents mixed results, either in terms of naturally occurring situations (Bar-Ilan and Sacerdote 2004; Gneezy and Rustichini 2000a; Frey and Meier 2004; 2003; Meier and Frey 2004) or field experiments (Cárdenas and Ostrom 2004; Apesteguia, Funk and Iriberri 2013; Huck and Rasul 2010; Bandiera, Barankay, and Rasul 2011; Chetty, Saez, and Sándor 2014; Haselhuhn et al. 2012). In this sense, the present paper brings new results to an open debate, by evaluating the behavior of users that respond to distinct types of incentives in a naturally occurring setting. ${ }^{3}$

Finally, the results here presented dialogue with an established literature related to social dilemmas, with a special emphasis on common-pool resource management (Ostrom 1990; Hardin 1968; Olson 1965; Demsetz 1967; Ostrom 1999; 2010). Although there exists a large volume of evidence related to social dilemmas in artificial settings - such as laboratory experiments (Dawes and Thaler 1988; Falk and Heckman 2009;

2 I thank an anonymous referee for suggesting the inclusion of references related to the economics of crime in the revised version of the paper. See Chalfin and McCrary (2017), Levitt and Miles (2006), Piehl and Williams (2011), and Polinsky and Shavell (2000) for examples of surveys on the theme.

3 See Chaudhuri (2011), Ledyard (1995), and Perc et al. (2017) for extensive surveys related to public goods experiments. Zelmer (2003) corresponds to a meta-analysis on the theme. 
Kagel 2009) - the present paper reports results in a naturally occurring setting, along the lines of recent studies (Gneezy, Leibbrandt and List 2016; Fehr and Leibbrandt 2011; Bauman and Rose 2011; Frey and Meier 2004; 2003). Most previous contributions in the literature emphasized examples related to themes such as forests, fisheries, and wildlife in general (Dietz, Ostrom and Stern 2003; Cárdenas 2003; Rustagi, Engel, and Kosfeld 2010; Ostrom 2007; Fehr and Leibbrandt 2011). Here I present an example of application related to an information commons. It is alsoworth noting that most contributions related to the inner workings of libraries have not explored collective action problems, such as those related to public goods provision and common-pool resource management (Apesteguia, Funk and Iriberri 2013; Getz 1989; Koechlin 2010; Paloheimo, Lettenmeier and Waris 2015). This paper differs from previous contributions by expanding the scope of analysis and focusing on the internal dynamics of an information commons (Bollier 2007; Hess and Ostrom 2007a; 2007b). ${ }^{4}$

\section{Testable Hypotheses}

The main hypotheses to be tested in this paper come from previous contributions related to the behavior of economists in laboratory and field settings. In a seminal paper, Marwell andAmes (1981) ran laboratory experiments testing the behavior of economists in public goodsgames. The authors reported the results of twelve experiments testing two versions of the free rider hypothesis. They concluded that economists, when represented by graduate students, tend to free ride considerably more than other subjects, with reported differences in contributions being statistically significant. According to the authors, there were two possible explanations for their results: first, students worried about economic incentives might self-select in economics ("selection hypothesis"); second, as time goes by, economics students may adapt their behavior to the theories they study ("indoctrination hypothesis").

Carter and Irons (1991) explored the robustness of Marwell and Ames' (1981) results by implementing a simple ultimatum bargaining game experiment to test whether economics students behave according to the predictions of rational choice models. The authors reported a result in which economics students, when playing the role of "responders" in ultimatum

\footnotetext{
${ }^{4}$ See Albergaria (2017a, b) and Albergaria and Saes (2018) for examples of analyses of this kind.
} 
games, accepted less money offers, while keeping more when in the role of "proposers". They also presented empirical evidence trying to disentangle "selection" and "indoctrination" effects among the experiment's subjects. In this case, results were mixed: while self-selection seemed to play a role in the choices reported, the same was not true for indoctrination effects. Overall, the authors concluded that, although the evidence is not conclusive, "economists are different" (Carter and Irons, 1991, p. 177).

Frank, Gilovich and Reagan (1993) investigated if exposure to self-interest models commonly used in economics affected students' behavior. The authors presented extensive evidence related to situations in which economics students might behave opportunistically when compared to students from other areas. For example, in one occasion, the authors ran 267 prisoners' dilemma experiments involving economics majors, as well as non-majors. When comparing defection rates between the two groups, they reported a $60.4 \%$ defection rate for economics majors, which was considerably higher than the value reported for non-majors (38.8\%). Interestingly, the authors also noticed that overall defection rates declined significantly as students advanced in school. They concluded that: (i) there were large differences in the extent to which economists and non-economists behaved self-interestedly; (ii) however, there were occasions when economists behaved in traditionally communitarian ways; and (iii) there were some evidence suggesting that differences in cooperativeness were caused in part by economics courses.

Yezer, Goldfarb and Poppen (1996) questioned the validity of Frank, Gilovich and Regan's (1993) study. According to the former authors, it was not obvious that exposure to economics would encourage less cooperative behavior. In particular, they emphasized the importance of drawing inferences based on subjects' behavior in actual (as opposed to hypothetical) situations. The authors presented the results of an interesting experiment, in which they dropped envelopes containing money in classrooms before classes begun (the "lost-letter experiment"). In this case, the return rate on lost letters was used as a measure of cooperation. The results of such an experiment suggested a considerable difference in cooperation rates between economics and non-economics majors. Contrarily to the evidence presented by Frank, Gilovich and Regan (1993) and other authors, Yezer, Goldfarb and Poppen's (1996) results suggest that economics students are far more cooperative than students from other disciplines. 
Given the above contributions, I test two alternative hypotheses in a library setting: ${ }^{5}$

Hypothesis 1 (Selection Hypothesis). Library users who present lower rates of rule compliance tend to choose business courses.

In the case of the first hypothesis, we would expect that the latter type of user would have, on average, a different type of compliance behavior, even when personal characteristics are controlled for. That is, users with lower compliance levels would self-select into business courses.

Hypothesis 2 (Indoctrination Hypothesis). Library users with a business background - such as accounting, economics, and management - tend to be indoctrinated by their exposition to business courses.

In the case of the latter hypothesis, we would expect that rule compliance differences between business and non-business users would increase as the former group receive more training in business theories. That is, exposition to business concepts and theories would indoctrinate users, and affect their compliance behavior.

It is worth noting that the main goal of this paper is to correlate library users' business background with their rule compliance behavior. Contrarily to some of the previously cited contributions, the present paper does not focus on opportunistic behaviors, such as free- riding. Given that the delays of some users may generate negative externalities to others in a library setting, the results here reported may be interpreted as a contribution to social dilemmas, with an emphasis on rule compliance, as mentioned above.

\section{Institutional Background}

In this paper, I study the behavior of library users covering more than 700,000 transactions during a 10 -year period. I have access to confidential daily data related to library users of a private university in São Paulo,

\footnotetext{
5 See Bauman and Rose (2011), Frey and Meier (2003, 2004, 2005), and Meier and Frey (2004) for detailed discussions related to these hypotheses.
} 
Brazil, for the 2006-2015 period. Specifically, the data contain detailed information on 16,232 individual users, covering 723,171 daily transactions. This corresponds to an unbalanced panel, since each user may borrow different numbers of specific library items at distinct moments. For example, one user may borrow two books on March $1^{\text {st }}$, and then borrow one more book on March $3^{\text {rd }}$, before returning previous items.

The private university under study has a long-standing tradition of offering business courses - such as accounting, economics, and management - at several levels, such as high school, undergraduate, graduate, and MBA courses. In terms of its undergraduate catalog, the university also offers additional courses, that I label as "non-business", such as international relations, advertising, and secretariat. The university has three campi in distinct locations of São Paulo. One important information regarding the libraries studied in this paper relates to their location and size. These libraries belong to different campi of the same university, two located in central neighborhoods in São Paulo (named units 1 and 2, for confidentiality reasons) and one located in an upper-class neighborhood (unit 3). Unit 1 is the oldest and largest library of the three: founded in 1902, it contained 31,193 books in the 2015 year. In the case of unit 2, it dates from 2006, and contains 2,883 books. Finally, unit 3 dates back to 2011, having 883 books.

The data contain information on users' socioeconomic characteristics such as gender, date of birth, and address - as well as library's confidential information, with each user's identification number, university category (high school, undergraduate, master's, MBA, former student, professor, and employee), and area of study (management, accounting, economics, international relations, advertising, and secretariat). For each user in the data, I am able to identify her department and category. This information allows me to build additional performance measures for each user in the sample, such as the number of items that she borrows every time she goes to the library, as well as a measure of delays over time (equal to the difference between the predicted and effective devolution dates for each item borrowed). I also build measures of early returns (in the case of users who return books before the predicted date) and books' usage (equal to the number of times that users pick a specific book). I complement the data with academic calendar information related to exam weeks occurred in the university over time. 
The data also contain the dates when each user borrowed specific items from the library, as well as each item's code and title. Given the latter information, I build a measure of area of expertise for each book in the sample, based on the Dewey Decimal Classification (DDC) system. Specifically, I label all the books in the data according to ten specific classes: (i) "000 - Computer Science, Information and General Works"; (ii) "100 - Philosophy and Psychology"; (iii) "200 - Religion"; (iv) "300 Social Sciences"; (v) "400 - Language”; (vi) "500 - Pure Science”; (vii) "600 - Technology"; (viii) "700 - Arts and Recreation"; (ix) "800 - Literature", and (x) "900 - History and Geography". 6

I also have access to libraries' official yearly reports. These reports contain rich institutional information related to the internal workings of all libraries under study. Based on this information, I am able to calculate the predicted devolution date for each user in the sample.

Table 1 presents information related to the workings of the libraries studied in this paper. The table's first column contains information on the number of library items that each user can borrow, based on the category that she belongs to (named "Item Counts"). The table's second and third columns contain the number of loan days per user category ("Loan Days"), as well as the distinct types of sanctions they face in the case of delays ("Sanction Type"), respectively:

Table 1 - Library rules by user category, 2006-2015

\begin{tabular}{lccc}
\hline USER CATEGORY & Item Counts & Loan Days & Sanction Type \\
\hline High School Student & 5 & 7 & Fine \\
Undergraduate Student & 5 & 7 & Fine \\
Master's Student & 7 & 15 & Fine \\
MBA Student & 5 & 7 & Fine \\
Former Student & 2 & 7 & Fine \\
University Employee & 3 & 7 & Daily Suspension \\
Professor & 7 & 15 & Daily Suspension \\
\hline
\end{tabular}

Source: author's calculations, based on library data.

Notes: (a) Observations correspond to the 2006-2015 period, covering 723,171 transactions by 16,232 library users.

In this specific case, the library's electronic system imposes a rule of 15 days for professors and master's students, and seven days for all other users. Each user can renew books after the predicted devolution date

${ }^{6}$ I thank Josiene Silva and Iruama Silva for providing the data necessary for such a classification, as well as several discussions related to the Dewey Decimal Classification (DDC) system. 
expires, conditional on a waiting list managed by library staff.Although I do not have access to information on the list contents, I can observe when users renew library items by comparing the dates of loans of the same item over time. There are also differences in terms of the number of items that each user can borrow from the library: while professors and master's students can borrow a maximum limit of seven items, students can borrow a maximum of five, and university employees can borrow three items.

Another important information related to the libraries under study concerns the sanctions deployed to avoid item delays, as well as their enforcement. Basically, the libraries employ two types of sanctions: (i) fines, and (ii) daily suspensions. In the case of the first type of sanctions (fines), they are valid for specific user categories, such as high school, undergraduate, graduate students, and former students (who are allowed to use the libraries after graduation). Specifically, in the case of delays, users in the above categories should pay a daily fine of $\mathrm{R} \$ 2.00$ ("dois reais", or approximately US\$ 0.35 in 2021 dollars) for each delayed item. For example, if an undergraduate returns two books with a delay of one day each, she has to pay a total value of $R \$ 4.00$ in fines. On the other hand, in the case of the second type of sanctions (daily suspensions), they are valid for professors, as well as university employees. In this specific case, users with delays face a penalty of three days for each delayed item. For example, if a professor returns two books with a delay of one day each, she has to face a suspension of six days from library services.

During the research stage for this paper, I had several official reunions with the libraries' staff, as well as informal conversations with some of their members. Based on those reunions, I was informed that the enforcement of sanctions by the staff was not perfect. That is, the fact that a user has delays in returning library items does not necessarily imply that she would effectively pay a corresponding fine or face daily suspensions, depending on her category. Additionally, in the case of one type of sanctions (fines), its nominal value remained the same ( $R \$ 2.00)$ for a period of approximately ten years (2006-2015). That is, the fines imposed by the library lost value in real terms, given the occurrence of a positive rate of inflation during the sample period under study. Although I try to control for such possibilities in the econometric estimations below, it is worth noting that they probably have important consequences in terms of the incentives faced by library users in this setting (more details below). ${ }^{7}$ 


\section{Material and Methods}

\section{Empirical Specification and Testable Hypotheses}

In this section I describe the empirical strategy employed in the paper. To assess the impact of business background on compliance behavior in the present setting, I estimate (1) via Ordinary Least Squares (OLS):

$\mathrm{Y}_{\text {ist }}=\alpha+\beta$ (Business) $+\mathrm{X}_{\text {ist }} \gamma+\mathrm{Z}_{\mathrm{st}} \lambda+\delta_{\mathrm{t}}+\theta_{\mathrm{st}}+\varepsilon_{\text {ist }}$

In the case of the above specification, Yist represents the delay for an individual user $i$, in library $s$, at instant $t$. The term "Business" corresponds to an indicator variable, which assumes unity value for users with a business background, and 0 , otherwise. I include users', books', and libraries' dummies as controls in the regressions below (captured by the term $\alpha)$, as well as month-year interactions to capture the effects of aggregate events $(\delta t)$. In the case of the term $\varepsilon$ ist, it has a conditional mean of zero $(\mathrm{E}(\varepsilon$ ist $\mid \mathrm{s}, \mathrm{t})=0)$. The parameter of interest in this context is $\beta$, which measures the effects of business background on compliance behavior. It is important to note that the estimates reported here do not have a causal interpretation. ${ }^{8}$

\section{Results}

This section presents the results of the empirical analysis developed in the paper. The section contains three subsections: (i) descriptive statistics, (ii) main results, and (iii) robustness checks. I discuss each of these subsections in greater detail below.

\footnotetext{
${ }^{7}$ I thank two anonymous referees for suggesting the inclusion of parts describing the sanctions employed in the libraries under study in this paper.

8 When performing robustness checks, I consider alternative methods of estimation, as well as causality issues (more details below). I thank the anonymous referees for suggestions along these lines.
} 


\section{Descriptive Statistics}

Table 2 presents descriptive statistics for the main variables used in the paper. The table's first and second columns display mean values for each variable, and their associated standard deviations, respectively. The table considers the total sample, as well as its main subsamples ("business" and "non-business" users).

Table 2 - Main variables' descriptive statistics, 2006-2015

\begin{tabular}{lcccccc}
\hline Sample & \multicolumn{2}{c}{ Total } & \multicolumn{3}{c}{ Business } & \multicolumn{2}{c}{ Non-business } \\
Variable & Mean & Std.Dev. & Mean & Std.Dev. & Mean & Std.Dev. \\
\hline Business & 0.83 & 0.38 & 1.00 & 0.00 & 0.00 & 0.00 \\
Female & 0.53 & 0.50 & 0.51 & 0.50 & 0.68 & 0.47 \\
Scholarship & 0.37 & 0.48 & 0.36 & 0.48 & 0.42 & 0.49 \\
18 to 23 years & 0.44 & 0.50 & 0.43 & 0.50 & 0.50 & 0.50 \\
24 to 30 years & 0.33 & 0.47 & 0.35 & 0.48 & 0.23 & 0.42 \\
31 to 40 years & 0.15 & 0.36 & 0.15 & 0.36 & 0.12 & 0.33 \\
41 to 50 years & 0.05 & 0.21 & 0.05 & 0.21 & 0.03 & 0.18 \\
51 to 60 years & 0.01 & 0.12 & 0.01 & 0.11 & 0.01 & 0.12 \\
60+ years & 0.00 & 0.04 & 0.00 & 0.04 & 0.00 & 0.06 \\
0 to 4 years in College & 0.89 & 0.31 & 0.91 & 0.28 & 0.86 & 0.35 \\
Delays & 1.42 & 8.16 & 1.40 & 7.56 & 1.51 & 10.69 \\
Frequency (Delays) & 0.40 & 0.49 & 0.40 & 0.49 & 0.39 & 0.49 \\
Loans' Effective Duration & 7.42 & 8.89 & 7.36 & 8.25 & 7.33 & 11.4 \\
Arts and Recreation Books & 0.02 & 0.15 & 0.02 & 0.12 & 0.06 & 0.23 \\
History and Geography Books & 0.01 & 0.11 & 0.01 & 0.09 & 0.04 & 0.19 \\
Language Books & 0.02 & 0.14 & 0.01 & 0.12 & 0.05 & 0.21 \\
Literature Books & 0.04 & 0.19 & 0.03 & 0.16 & 0.10 & 0.30 \\
Philosophy and Psychology & 0.02 & 0.16 & 0.02 & 0.15 & 0.03 & 0.16 \\
Books & 0.00 & 0.02 & 0.00 & 0.02 & 0.00 & 0.04 \\
Religion Books & 0.08 & 0.27 & 0.08 & 0.27 & 0.06 & 0.24 \\
Science Books & 0.28 & 0.45 & 0.27 & 0.45 & 0.33 & 0.47 \\
Social Science Books & 0.48 & 0.50 & 0.52 & 0.50 & 0.31 & 0.46 \\
Technology Books & & 723,171 & & 592,675 & & 122,946 \\
Observations & & & & & & \\
\hline
\end{tabular}

Source: author's calculations, based on library data.

Notes: (a) Observations correspond to the 2006-2015 period, covering 723,171 transactions by 16,232 library users.

For the main period of analysis in this paper (2006-2015), I observe 723,171 librarytransactions made by 16,232 users. These users are, on average, 26 years old, with similar proportions in terms of gender. Among these users, $22 \%$ are in their first year in college, while $37 \%$ hold a scholarship. In ter$\mathrm{ms}$ of categories, most library users are either undergraduates $(66 \%)$ or 
MBA students (21\%). In terms of performance measures, users borrow, on average, 2.65 library items, while keeping them for an approximate period of 7.42 days. Book delays are around 1.42 days, with their frequency being around $40 \%$ (there is a similar proportion - in terms of magnitude - for early returns). In terms of areas of study, the vast majority of users have a background in either accounting (36\%), management (33\%), or economics (14\%), with a total proportion of $83 \%$ of users with a business background. The other users have a background in international relations (5\%), advertising $(4 \%)$, and secretariat (2\%), as well as other courses which do not have a precise business definition. This is an intuitive result, given the fact that the university in which the libraries are located corresponds to a business school. On the other hand, it is worth noting that there are significant differences - in terms of descriptive statistics - between the business and non-business samples, which could bias some of the conclusions discussed below. I investigate the effects of such differences in the robustness section.

\section{Main Results}

In this section, I present the results of the empirical analysis performed in the paper. Table 3 contains the results of OLS estimations for the 20062015 period. In the table, the dependentvariable corresponds to delays per user in the period, measured in days. The table's first column corresponds to an econometric specification for equation (1) with no controls. In the table's second column, I add a rich set of user dummies to capture their time-invariant characteristics: gender, age group, area of study, and time at school. In the third column, I also include library dummies, such as their location, and staff size. In the fourth column, I include book dummies that reflect their DDC classifications, as a way to capture differences among books and users' areas of study. Finally, in the fifth column, I repeat the previous specifications, but I include month-year dummies, in order to control for the impacts of aggregate shocks that may affect the results, given the extended period covered in the sample(2006-2015). I also report coefficient estimates for both types of punishment in the library:

(i) monetary fines, and (ii) daily suspensions. I do this to capture the importance of distinct types of incentives that could affect users' behavior in the present setting. In the case of all estimations, I cluster standard errors by library users' identification numbers. ${ }^{9}$ 
Table 3 - Effects of Business Background on Delays, OLS Estimates, 2006-2015

\begin{tabular}{|c|c|c|c|c|c|}
\hline VARIABLES & $\begin{array}{c}1) \\
\text { Delays } \\
\text { (OLS) }\end{array}$ & $\begin{array}{c}(2) \\
\text { Delays } \\
\text { (OLS) }\end{array}$ & $\begin{array}{c}(3) \\
\text { Delays } \\
\text { (OLS) }\end{array}$ & $\begin{array}{c}4) \\
\text { Delays } \\
\text { (OLS) }\end{array}$ & $\begin{array}{c}(5) \\
\text { Delays } \\
\text { (OLS) }\end{array}$ \\
\hline Business & $\begin{array}{c}0.01 \\
(0.012)\end{array}$ & $\begin{array}{c}-0.01 \\
(0.013)\end{array}$ & $\begin{array}{c}-0.02^{*} \\
(0.013)\end{array}$ & $\begin{array}{c}-0.02^{*} \\
(0.013)\end{array}$ & $\begin{array}{l}-0.03^{* *} \\
(0.013)\end{array}$ \\
\hline Monetary Fine & $\begin{array}{l}0.01^{* * *} \\
(0.004)\end{array}$ & $\begin{array}{l}0.01^{\star * *} \\
(0.004)\end{array}$ & $\begin{array}{l}0.01^{* * *} \\
(0.004)\end{array}$ & $\begin{array}{l}0.01^{* * *} \\
(0.004)\end{array}$ & $\begin{array}{l}0.01^{* * *} \\
(0.004)\end{array}$ \\
\hline Daily Suspension & $\begin{array}{l}-0.00^{* * *} \\
(0.000)\end{array}$ & $\begin{array}{c}-0.00^{* * *} \\
(0.000)\end{array}$ & $\begin{array}{r}-0.00 \\
(0.000)\end{array}$ & $\begin{array}{r}-0.00 \\
(0.000)\end{array}$ & $\begin{array}{r}0.00 \\
(0.000)\end{array}$ \\
\hline User Dummies & No & Yes & Yes & Yes & Yes \\
\hline Library Dummies & No & No & Yes & Yes & Yes \\
\hline Book Dummies & No & No & No & Yes & Yes \\
\hline Months $x$ Years & No & No & No & No & Yes \\
\hline Observations & 715,621 & 715,621 & 714,646 & 714,646 & 714,646 \\
\hline Adj. R-squared & 0.0450 & 0.0501 & 0.0542 & 0.0542 & 0.114 \\
\hline
\end{tabular}

Notes: (a) The dependent variable in the specifications corresponds to the average delays (in days) per user in each library studied in this paper. (b) Standard errors clustered by user's identification number (reported in parentheses). (c) "User Dummies" correspond to a set of dummies for users' gender (female $=1$ ), academic financial support (scholarship =1), group ages (18-23, 24-30, 31-40, 41-50, 51- 60, $60+$ ), category (undergraduate, master's, graduate, former student, employee, and professor), and time at school (0 to 4 years). (d) "Library Dummies" correspond to a set of dummies for each library in the sample, as well as their books. (e) "Book Dummies" correspond to a set of dummies representing the Dewey Decimal Classification (DDC) system. (f) "Months x Years" correspond to dummies representing interactions between months and years. (g) Statistical significance: ${ }^{*} \mathrm{p}<0.10,{ }^{* *} \mathrm{p}<0.05,{ }^{* * *} \mathrm{p}<0.01$.

One main result emerges from the table: although there is not a statistically significant effect of library users' business background on rule compliance in the case of the two first columns in the table, such a pattern is reversed once I control for library users', libraries', and books'characteristics, as well as aggregate shocks. That is, contrarily to previous contributions relating business background to opportunistic behaviors (Bauman and Rose, 2011; Carter and Irons, 1991; Ruske, 2015), I find a negative correlation between business background and book delays in this specific setting. This result is in line with recent contributions in economics and business ethics that question the influence of business education on important behavioral traits, such as individual orientation, cooperation, and poli-

9 In the original version of the paper, I clustered standard errors by the number of courses offered at the university (Albergaria 2018). The main results here reported do not change in the case of such a procedure.I thank an anonymous referee for suggesting me to cluster standard errors by library users' identification numbers. 
tical views, for example(Godos-Díez, Fernández-Gago and Cabeza-García 2015; Delis, Hasan and Iosifidi 2019; Frey and Meier 2005; Meier and Frey 2004; Frey and Meier 2003). On the other hand, the results reported in the table suggest that different types of punishment have distinct deterrent effects in this setting: while monetary fines have a positive correlation with delays, the effects of daily suspensions vanish once I control for additional characteristics of users, libraries, and books. Although these are interesting results, they could be biased for several reasons, such as the choice of specific estimation techniques, or sample selection issues, for example. Given these possibilities, I present the results of several robustness checks in the next section.

\section{Robustness Checks}

In the previous section, I reported a result in which business background does not affect compliance behavior in a library setting. Although this is an interesting result, it may be biased for several reasons. In this section, I present results from distinct robustness tests to validate the main results reported above. ${ }^{10}$

Table 4 presents the results of estimations focused on testing the alternative hypotheses described above ("selection" and "indoctrination"), as originally suggested by previous studies in the literature. Specifically, following the contributions of Frey and Meier (2003, 2004, 2005), I run probit regressions for a specific subsample including undergraduate students only, in which the dependent variable corresponds either to (i) the frequency of delays (denoted "Freq(Late)"), or (ii) the frequency of early book returns ("Early"). I do this to evaluate the effects of business background on the compliance behavior of specific users. If selection effects prevail in this setting, then one should expect a result in which undergraduates who were not exposed to economic concepts (such as freshmen) would present a worst performance - in terms of compliance behavior - when compared to older students. On the other hand, if indoctrination effects prevail, then one would expect a situation in which undergraduates who were more exposed to economic concepts (such as seniors and main stage students) would present a worst performance, when compared to freshmen.

${ }^{10}$ I thank the anonymous referees for suggesting most of the robustness checks reported in this section, which greatly improved the revised version of the paper. 
Table 4 - Robustness: "Selection" and "Indoctrination" Effects

Probit Estimates, 2006-2015

\begin{tabular}{|c|c|c|c|c|}
\hline VARIABLES & $\begin{array}{c}\text { (1) } \\
\text { Freq(Late) }\end{array}$ & $\begin{array}{c}(2) \\
\text { Freq(Late) }\end{array}$ & $\begin{array}{c}(3) \\
\text { Early }\end{array}$ & $\begin{array}{c}(4) \\
\text { Early }\end{array}$ \\
\hline Business & $\begin{array}{l}-0.05^{\star} \\
(0.032)\end{array}$ & $\begin{array}{c}-0.15 \\
(0.102)\end{array}$ & $\begin{array}{c}0.06 \\
(0.043)\end{array}$ & $\begin{array}{c}0.16 \\
(0.131)\end{array}$ \\
\hline Freshmen & $\begin{array}{l}-0.18^{\star * *} \\
(0.042)\end{array}$ & $\begin{array}{l}-0.30^{* * *} \\
(0.108)\end{array}$ & $\begin{array}{l}0.18^{\star \star \star} \\
(0.052)\end{array}$ & $\begin{array}{l}0.32^{* *} \\
(0.139)\end{array}$ \\
\hline Seniors & $\begin{array}{l}-0.09^{* * *} \\
(0.028)\end{array}$ & $\begin{array}{l}-0.16 \\
(0.095)\end{array}$ & $\begin{array}{l}0.08^{* *} \\
(0.035)\end{array}$ & $\begin{array}{c}0.12 \\
(0.122)\end{array}$ \\
\hline Main Stage & $\begin{array}{l}-0.13^{\star * *} \\
(0.034)\end{array}$ & $\begin{array}{l}-0.22^{* *} \\
(0.094)\end{array}$ & $\begin{array}{l}0.13^{\star * \star} \\
(0.042)\end{array}$ & $\begin{array}{c}0.22^{*} \\
(0.118)\end{array}$ \\
\hline Freshmen $x$ Business & & $\begin{array}{c}0.13 \\
(0.102)\end{array}$ & & $\begin{array}{l}-0.15 \\
(0.131)\end{array}$ \\
\hline Seniors $\times$ Business & & $\begin{array}{c}0.07 \\
(0.095)\end{array}$ & & $\begin{array}{c}-0.04 \\
(0.120)\end{array}$ \\
\hline Main Stage $x$ Business & & $\begin{array}{c}0.10 \\
(0.092)\end{array}$ & & $\begin{array}{c}-0.09 \\
(0.113)\end{array}$ \\
\hline Semesters & $\begin{array}{l}-0.05^{\star * *} \\
(0.008)\end{array}$ & $\begin{array}{l}-0.05^{* \star *} \\
(0.008)\end{array}$ & $\begin{array}{l}0.06^{\star \star *} \\
(0.009)\end{array}$ & $\begin{array}{l}0.06^{\star \star *} \\
(0.009)\end{array}$ \\
\hline$(\text { Semesters })^{2}$ & $\begin{array}{l}0.00^{* * *} \\
(0.001)\end{array}$ & $\begin{array}{l}0.00^{* * *} \\
(0.001)\end{array}$ & $\begin{array}{l}-0.00^{* * *} \\
(0.001)\end{array}$ & $\begin{array}{l}-0.00^{\star * \star} \\
(0.001)\end{array}$ \\
\hline $\begin{array}{l}\text { Observations } \\
\text { Pseudo R-squared }\end{array}$ & $\begin{array}{c}463,913 \\
0.0148\end{array}$ & $\begin{array}{c}463,913 \\
0.0149\end{array}$ & $\begin{array}{c}463,913 \\
0.0149\end{array}$ & $\begin{array}{c}463,913 \\
0.0150\end{array}$ \\
\hline
\end{tabular}

Notes: (a) The dependent variables in the specifications corresponds to the frequency of delays per user (first and second columns), and the proportion of early devolutions (third and fourth columns). (b) Standard errors clustered by user's identification number (reported in parentheses). (c) Statistical significance: ${ }^{*} \mathrm{p}<0.10,{ }^{* *} \mathrm{p}<0.05,{ }^{* * *} \mathrm{p}<0.01$.

The results obtained from such an experiment initially suggest that, on average, freshmen present a better performance, in terms of rule compliance, when compared to older undergraduates. Specifically, in the case of the table's first and third columns, students in the first year of college present a lower frequency of delays in returning books, when compared to more advanced students, at the same time that they present a higher frequency of early returns. However, it is worth noting that the effects of business background on compliance behavior disappear once I control for users' university stages, as well as their interactions with background. In general terms, these results suggest that business background does not affect the compliance measures considered in the table, in accordance with previous results reported in the paper. 
In Table 5, I present estimates in which I substitute the dependent variable with alternative measures of library users' compliance. These variables are the following: the effective duration of loans (in days), the proportion of early devolutions, the frequency of delays, the number of books borrowed by each user, and the number of fines imposed on them. Given the distinct nature of each one of these dependent variables, I employ different estimation methods. In the first column of the table, I present the results of OLS estimations, correlating business background and loans' effective duration. In the second and third columns, I present results of probit estimations, since the dependent variables in these columns correspond to a proportion between zero and one. In the fourth and fifth columns, I employ count-data models, based on the Negative Binomial distribution. I employ such models, since the dependent variables in these columns correspond to count data (non-negative integer numbers), with overdispersion patterns.

In the second part of the table - columns (6) to (9) - I redo the estimations containing delays as the dependent variable, but employing different estimation methods. In this specific case, given the fact that library delays correspond to a count data variable with a large proportion of zeros, I present estimations based on the Poisson and Negative Binomial models, as well as their zero-inflated versions (in which the term "ZIP" denotes "Zero-inflated Poisson", while the term "ZINB" denotes "Zeroinflated Negative Binomial"). In the case of each specification, I include the same set of covariates as before. Two interesting patterns emerge from the results in the table: first, there is not a significant correlation between business background and compliance behavior in the majority of the performance measures considered; second, in the case of count data models, as well as its zero-inflated versions, there is a negative correlation among business background and rule compliance, which suggests that library users with such a background present a better performance - in terms of compliance behavior - when compared to other users. ${ }^{11}$

${ }^{11}$ For more details related to count data models, see Blevins et al. (2015), Cameron and Trivedi (1990, 2009), and Trivedi (2010). In the case of zero-inflated count data models, see Desmarais and Harden (2013), Long and Freese (2001), and Vuong (1989). See also Guimarães and Portugal (2010) for a description of an iterative approach for the estimation of linear regression models with high-dimensional fixed effects. I thank an anonymous referee for the latter reference, as well as suggesting the inclusion of count data models' estimates in the revised version of the paper. 


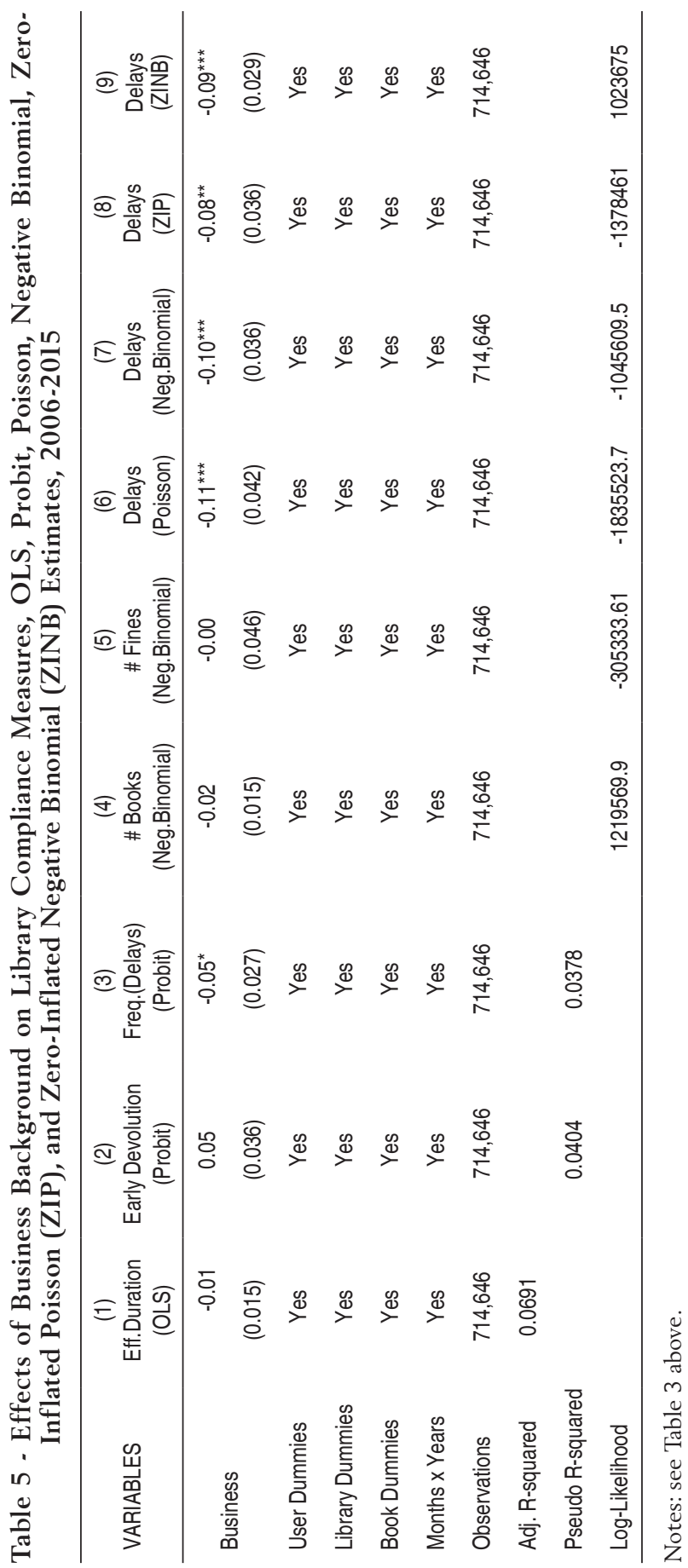


Table 6 presents robustness checks based on different subsamples. I do this to verify whether the previous results are robust compared to alternative sample definitions. Each column in the table considers a different sample. In the first two columns, I consider samples based on undergraduates and students (undergraduates, master's, MBA, and graduate students), only. Since most contributions in the literature focus on the behavior of university students, I replicate the above analysis with these samples to see if the use of specific user categories could affect my results. Results remain the same in this case, indicating that the empirical patterns here reported do not depend on user categories.

In the third column, I present estimates in which I keep exam weeks in the sample, only. I consider this specific sample as a test for opportunistic behavior in a library setting. Specifically, if users with a business background are more opportunistic than similar users with different backgrounds, then one would expect a higher proportion of delays in times when the competition for books is higher, such as exam weeks, for example. Even in the case of this reduced sample, I cannot find a significant effect of business education on compliance.

In the fourth and fifth columns of the table, I test the possibility that my results may be driven by psychological biases of users, such as inattention patterns (Gabaix 2019). Given the increasing amount of information that most people face today, as well as their cognitive limitations, it is not feasible to simultaneously focus their attention on all events they face (Simon 1955). As a result, inattention behavior may arise in different situations, even when people receive constant reminders to behave in a different manner. Although reminders can work in promoting rule compliance (Apesteguia, Funk and Iriberri 2013), there is evidence suggesting that individuals may not meet a deadline even when it is profitable to do so. If inattention affects delays in this setting, then one should expect a higher proportion of delays on dates in which procrastination play a predominant role, such as days before weekends or holidays, as suggested by previous contributions in behavioral finance, for example (DellaVigna and Pollet 2009; Barber and Odean 2008; Hirshleifer, Lim and Teoh 2009). This is the reason why I consider samples based on days before holidays (fourth column), as well as Fridays (fifth column). 
Table 6 - Robustness: Selected Subsamples, OLS Estimates, 2006-2015

\begin{tabular}{lccccc}
\hline VARIABLES & $\begin{array}{c}(1) \\
\text { Undergraduates Only }\end{array}$ & $\begin{array}{c}(2) \\
\text { Students Only }\end{array}$ & $\begin{array}{c}(3) \\
\text { Exam Weeks }\end{array}$ & $\begin{array}{c}(4) \\
\text { Holidays }(t-1)\end{array}$ & $\begin{array}{c}(5) \\
\text { Fridays }\end{array}$ \\
\hline Business & -0.02 & -0.02 & -0.00 & -0.04 & -0.03 \\
& $(0.027)$ & $(0.021)$ & $(0.032)$ & $(0.025)$ & $(0.018)$ \\
User Dummies & Yes & Yes & Yes & Yes & Yes \\
Library Dummies & Yes & Yes & Yes & Yes & Yes \\
Book Dummies & Yes & Yes & Yes & Yes & Yes \\
Months x Years & Yes & Yes & Yes & Yes & Yes \\
Observations & 474,148 & 672,133 & 75,940 & 7,032 & 104,304 \\
Adj. R-squared & 0.206 & 0.228 & 0.250 & 0.240 & 0.248 \\
\hline
\end{tabular}

Notes: see Table 3 above.

In table 7, I evaluate the effects of different university backgrounds on compliance behavior. Given that the two main classifications employed here - "business" and "non-business" - encompass distinct courses, it is worth exploring if differences in compliance rates are due to differences in the specific training of library users. In doing so, I estimate saturated regressions for a subsample including only undergraduates from the university's main majors: (i) accounting, (ii) economics, (iii) management, (iv) advertising, (v) international relations, and (vi) secretariat. Once again, I progressively include users', libraries', books', and month-year dummies to control for factors that could bias estimates.

Table 7 - Robustness: Undergraduate Majors, OLS Estimates, 2006-2015

\begin{tabular}{|c|c|c|c|c|c|}
\hline & (1) & (2) & (3) & (4) & (5) \\
\hline VARIABLES & $\begin{array}{l}\text { Delays } \\
\text { (OLS) }\end{array}$ & $\begin{array}{l}\text { Delays } \\
\text { (OLS) }\end{array}$ & $\begin{array}{l}\text { Delays } \\
\text { (OLS) }\end{array}$ & $\begin{array}{l}\text { Delays } \\
\text { (OLS) }\end{array}$ & $\begin{array}{l}\text { Delays } \\
\text { (OLS) }\end{array}$ \\
\hline Accounting & $\begin{array}{c}-0.01 \\
(0.043)\end{array}$ & $\begin{array}{c}-0.01 \\
(0.047)\end{array}$ & $\begin{array}{c}-0.01 \\
(0.045)\end{array}$ & $\begin{array}{c}-0.00 \\
(0.043)\end{array}$ & $\begin{array}{c}-0.02 \\
(0.045)\end{array}$ \\
\hline Economics & $\begin{array}{c}-0.06 \\
(0.044)\end{array}$ & $\begin{array}{c}-0.07 \\
(0.047)\end{array}$ & $\begin{array}{c}-0.07 \\
(0.045)\end{array}$ & $\begin{array}{c}-0.06 \\
(0.043)\end{array}$ & $\begin{array}{l}-0.08^{*} \\
(0.046)\end{array}$ \\
\hline Management & $\begin{array}{c}-0.04 \\
(0.043)\end{array}$ & $\begin{array}{c}-0.05 \\
(0.047)\end{array}$ & $\begin{array}{c}-0.05 \\
(0.045)\end{array}$ & $\begin{array}{c}-0.05 \\
(0.043)\end{array}$ & $\begin{array}{c}-0.05 \\
(0.045)\end{array}$ \\
\hline Advertising & $\begin{array}{c}0.04 \\
(0.045)\end{array}$ & $\begin{array}{c}0.04 \\
(0.049)\end{array}$ & $\begin{array}{c}0.07 \\
(0.048)\end{array}$ & $\begin{array}{c}0.07 \\
(0.046)\end{array}$ & $\begin{array}{c}0.07 \\
(0.048)\end{array}$ \\
\hline Int. Relations & $\begin{array}{l}-0.12^{\star \star} \\
(0.050)\end{array}$ & $\begin{array}{l}-0.11^{* *} \\
(0.053)\end{array}$ & $\begin{array}{l}-0.11^{\star \star} \\
(0.052)\end{array}$ & $\begin{array}{l}-0.11^{\star *} \\
(0.050)\end{array}$ & $\begin{array}{l}-0.12^{\star *} \\
(0.050)\end{array}$ \\
\hline Secretariat & $\begin{array}{c}0.03 \\
(0.047)\end{array}$ & $\begin{array}{c}0.03 \\
(0.051)\end{array}$ & $\begin{array}{c}0.03 \\
(0.049)\end{array}$ & $\begin{array}{c}0.03 \\
(0.047)\end{array}$ & $\begin{array}{c}0.03 \\
(0.048)\end{array}$ \\
\hline User Dummies & No & Yes & Yes & Yes & Yes \\
\hline Library Dummies & No & No & Yes & Yes & Yes \\
\hline $\begin{array}{l}\text { Book Dummies } \\
\text { Months } x \text { Years }\end{array}$ & $\begin{array}{l}\text { No } \\
\text { No }\end{array}$ & $\begin{array}{l}\text { No } \\
\text { No }\end{array}$ & No & Yes & Yes \\
\hline $\begin{array}{l}\text { Montns X Years } \\
\text { Observations }\end{array}$ & $\begin{array}{l}\text { No } \\
474,098\end{array}$ & $\begin{array}{c}\text { No } \\
474,098\end{array}$ & 473,513 & 473,513 & 473,513 \\
\hline Adj. R-squared & 0.00255 & 0.00579 & 0.0106 & 0.0545 & 0.114 \\
\hline
\end{tabular}

Notes: see table 3 above. 
The results reported in the table suggest that, although there are a few differences among university majors in terms of magnitudes, such differences disappear once I control for users', books', and libraries' characteristics, as well as aggregate shocks. In particular, the table's results suggest that users majoring in economics and international relations present, on average, less delays than other majors, which reinforces some of the previous results. ${ }^{12}$

One possible source of bias in the present context relates to the specific setting under study. Given that some users go to the library often, they may have more incentives to comply with library rules. In principle, this possibility could bias the results here reported: more frequent users, representing the vast majority of the sample, would present a more adequate behavior in terms of rule compliance. To investigate such a possibility, I consider a subsample which contains users who went to the library one single time during the 2006-2015 period. The resulting subsample contains 1,111 observations. Table 8 presents the results of such an experiment, for different specifications of equation (1). The estimates reported in the table suggest that there are no effects of business background on rule compliance in the case of this specific subsample.

Table 8 - Robustness: One-time Library Users, OLS Estimates, 2006-2015

\begin{tabular}{lccccc}
\hline \multirow{2}{*}{ VARIABLES } & $\begin{array}{c}(1) \\
\text { Delays } \\
(\mathrm{OLS})\end{array}$ & $\begin{array}{c}(2) \\
\text { Delays } \\
(\mathrm{OLS})\end{array}$ & $\begin{array}{c}(3) \\
\text { Delays } \\
(\mathrm{OLS})\end{array}$ & $\begin{array}{c}(4) \\
\text { Delays } \\
(\mathrm{OLS})\end{array}$ & $\begin{array}{c}(5) \\
\text { Delays } \\
(\mathrm{OLS})\end{array}$ \\
\hline Business & -0.03 & -0.01 & -0.07 & -0.14 & -0.15 \\
User Dummies & $(0.073)$ & $(0.106)$ & $(0.109)$ & $(0.093)$ & $(0.094)$ \\
Library Dummies & No & Yes & Yes & Yes & Yes \\
Book Dummies & No & No & Yes & Yes & Yes \\
Months x Years & No & No & No & Yes & Yes \\
Observations & No & No & No & No & Yes \\
Adj. R-squared & 1,111 & 1,111 & 1,107 & 1,107 & 1,107 \\
\hline
\end{tabular}

Notes: see table 3 above.

${ }^{12}$ See Angrist and Pischke (2009, ch. 3) for a brief discussion on saturated regression models. 
Another source of bias in this setting relates to preexisting differences between business and non-business users, which could affect the above estimates. Specifically, given the differences between business and non-business groups of library users - in terms of their main characteristics - there is the possibility that such groups are not entirely comparable, since the choice of business major may not be random. To address such a possibility, I follow Galiani et al. (2005) and employ a double-robust propensity score matching (PSM) method to estimate average treatment effects (ATE), as well as fixed-effects (FE) estimates, relating business background and compliance behavior. ${ }^{13}$

In the case of the first step of this method, I employ a logit model to estimate the probability that library users belong to the treatment group (business), and build a common support for the observations in the sample which have similar propensity score values. In the second step of the method, I estimate a panel fixed effects regression in which I weigh each observationin the sample by its respective propensity score. Table 9 presents balancing results for the matched and unmatched samples, while table 10 contains the main results of estimations forATE and FE effects.

${ }^{13}$ I thank Fernando Postali for suggesting this empirical strategy, as well as related references (see Carnicelli and Postali, 2012). See also Abadie et al. (2004), Becker and Ichino (2002), and Dehejia and Wahba (2002) for expositions related to the implementation of matching estimators for average treatment effects. Li (2012) provides a detailed survey of applications based on the propensity score method (PSM), with an emphasis on the estimation of causal effects. 
Table 9 - Robustness: Balancing Properties Business and Non-Business Library Users, 2006-2015

\begin{tabular}{|c|c|c|}
\hline \multirow{2}{*}{ Variable } & \multicolumn{2}{|c|}{ Difference } \\
\hline & Unmatched Sample & Matched Sample \\
\hline Female & $-0.174^{* * *}$ & -0.002 \\
\hline Scholarship & $-0.059^{* * *}$ & $-0.004^{* *}$ \\
\hline 18 to 23 years & $-0.0703^{\star \star \star}$ & -0.003 \\
\hline 24 to 30 years & $0.126^{* \star *}$ & 0.000 \\
\hline 31 to 40 years & $0.028^{\star \star \star}$ & -0.001 \\
\hline 41 to 50 years & $0.013^{\star \star *}$ & $0.001^{*}$ \\
\hline 51 to 60 years & $-0.001^{* * *}$ & $0.001^{* \star *}$ \\
\hline $60+$ years & $-0.002^{\star \star *}$ & $0.001^{* \star *}$ \\
\hline 0 to 4 years in College & $0.054^{* * *}$ & -0.001 \\
\hline Arts and Recreation Books & $-0.042^{* * *}$ & -0.000 \\
\hline History and Geography Books & $-0.029^{\star * \star}$ & $0.001^{*}$ \\
\hline Language Books & $-0.033^{\star * \star}$ & -0.000 \\
\hline Literature Books & $-0.069^{\star \star \star}$ & $0.003^{\star \star \star}$ \\
\hline Philosophy and Psychology Books & $-0.003^{\star \star *}$ & -0.000 \\
\hline Religion Books & $-0.001^{* * *}$ & 0.000 \\
\hline Science Books & $0.022^{* * *}$ & $0.004^{\star * *}$ \\
\hline Social Science Books & $-0.059^{* * *}$ & $-0.005^{\star * \star}$ \\
\hline Technology Books & $0.205^{\star \star \star}$ & -0.002 \\
\hline Library Unit 1 & $-0.058^{\star \star \star}$ & -0.001 \\
\hline Library Unit 3 & $0.002^{\star \star \star}$ & -0.000 \\
\hline
\end{tabular}

Source: author's calculations, based on library data.

Notes: (a) Observations correspond to the 2006-2015 period, covering 723,171 transactions by 16,232 library users. (b) The double-robust propensity score matching (PSM) procedure here employed follows Galiani et al. (2005). (c) Statistical significance: ${ }^{*} \mathrm{p}<0.10,{ }^{* *} \mathrm{p}<0.05$, ${ }^{* * *} \mathrm{p}<0.01$.

Table 10 - Robustness: Matched Sample (PSM) ATE and FE Estimates, 2006-2015".

\begin{tabular}{lcc}
\hline VARIABLES & $\begin{array}{c}(1) \\
\text { Delays } \\
(\text { ATE) }\end{array}$ & $\begin{array}{c}(2) \\
\text { Delays } \\
(\mathrm{FE})\end{array}$ \\
\hline Business & -0.17 & 0.02 \\
User Dummies & $(0.125)$ & $(0.030)$ \\
Library Dummies & Yes & Yes \\
Book Dummies & Yes & Yes \\
Months x Years & Yes & Yes \\
Observations & Yes & Yes \\
Adj. R-squared & 667,389 & 667,389 \\
\hline
\end{tabular}

Notes: see Table 9 above. 
The results reported in the tables suggest that, although I cannot fully control for unobserved differences among business and non-business groups, there is not a significant effect of business background on compliance behavior. That is, even when considering groups of library users with similar observed characteristics, I do not find a statistically significant correlation between the main variables of interest.

In general, a first inspection of the robustness checks presented in this section confirms that previous results remain virtually the same. These results lend confidence to the claim that, in the case of most specifications here considered, there is not a significant effect of business education on compliance behavior.

\section{Conclusions and discussion}

The present paper studied the impacts of business background on rule compliance in an information commons (libraries). Employing a novel dataset related to more than 700,000 transactions in distinct libraries during a 10-year period (2006-2015), I estimate the effects of business major on library performance measures, by comparing the behavior of distinct categories of users (students, professors, and employees) over time, while controlling for their time-invariant characteristics. The results obtained suggest that there is no evidence of a significant effect of business education on compliance behavior in this specific setting. In fact, some of the estimates here reported suggest a negative correlation between business background and compliance behavior. These results are in line with recent contributions in business ethics that question the influence of business education on important behavioral traits, such as individual orientation, cooperation, and political views (Godos-Díez, Fernández-Gago and Cabeza-García 2015; Delis, Hasan and Iosifidi 2019; Frey and Meier 2005; Meier and Frey 2004; Frey and Meier 2003).

In terms of strengths, this paper is probably one of the first attempts to evaluate individual behavior in an information commons. While most of the literature on the theme concentrated on determining precise definitions of related terms (Hess and Ostrom 2007a; 2007b; Bollier 2007; Rosen and Carr 1997) - such as the new role of libraries in the digital age, or the dif- 
fusion of the Internet - there were few efforts aimed at empirically testing the predictions derived from the characteristics of an information commons. Additionally, it is worth noting that the repeated-measure nature of the phenomenon here studied constitutes a strength of this paper (since users borrow different library items over time), given that most collectiveaction situations reported in laboratory and field experiments involve repeated interaction (Andreoni and Croson, 2008; Cárdenas and Ostrom, 2004; Ostrom, 2000). In fact, contrarily to most research related to laboratory experiments, in which there is the possibility that part of the subject pool start gaming the experimenter - generating "experimenter demand effects" -, the longitudinal data used in this paper allow me to observe individual behavior in a real-world setting during distinct moments of time, not being subject to such a bias.

In terms of limitations, the results here presented may lack external validity, since I study user behavior in different libraries of the same university. Although there seems to be considerable diversity among library units and their users, one may argue that these results reflect a very specific institutional setting. Similarly, there is a well-known criticism related to laboratory experiments, stating that their exclusive reliance on student behavior may compromise external validity (Fréchette, 2015; Kagel, 2009; List, 2011). In this case, one advantage of the present findings is that they focus on the behavior of distinct users, such as professors, high school, undergraduate, and graduate students, as well as university employees. This feature of the data lends confidence against such criticisms, at the same time that it presents some of the advantages related to behavior observed in the field and in naturally-occurring settings (Apesteguia, Funk and Iriberri 2013; Haselhuhn et al. 2012; Fehr and Leibbrandt 2011; Goeree, McConnell and Mitchell 2010; Frey and Meier 2004; 2003; Meier and Frey 2004).

Future research could benefit from an increasing focus on behavior in distinct settings. Although there were significant contributions in this direction coming from the work of Elinor Ostrom and coauthors (Dietz, Ostrom and Stern 2003; Vollan and Ostrom 2010; Ostrom 1990; 2010; 1999; 2005), there is still room for improvement, either in terms of field or natural experiments. In this case, it is worth citing two novel contributions. Fehr and Leibbrandt (2011) present results of laboratory and field experiments focused on the behavior of Brazilian anglers in a lake, a typical example of a common-pool resource. In a similar spirit, Gneezy, 
Leibbrandt and List (2013) study the evolution of social norms among anglers, conditional on their working routines. In both cases, the authors stress the importance of psychological traits predicting observed behavior in the field, as well as the importance of jointly considering the results of laboratory and field experiments, when evaluating social dilemmas. While there is a growing literature on experiments in several areas, such as economics and business (Falk and Heckman, 2009; Kagel, 2009; Smith, 1989), it seems clear that the current research on common-pool resource management could benefit from atendency to blend the results of laboratory and field experiments.

\section{References}

Abadie, A, D Drukker, J L Herr, and G W Imbens. 2004. "Implementing Matching Estimators for Average Treatment Effects in Stata." Stata Journal 4 (3): 290-311. https://doi.org/The Stata Journal.

Acemoglu, Daron, and Matthew O Jackson. 2017. "Social Norms and the Enforcement of Laws." Journal of the European Economic Association 15 (2): 245-95. https://doi.org/10.1093/jeea/jvw006.

Akerlof, George A, and Rachel E Kranton. 2000. "Economics and Identity." Quarterly Journal of Economics 115 (August): 715-53. https://doi.org/10.1162/003355300554881.

- 2005. "Identity and the Economics of Organizations." Journal of Economic Perspectives 19 (1): 9-32. https://doi.org/10.1257/0895330053147930.

Albergaria, Matheus. 2017a. "Fines, Externalities, and Transaction Costs: Essays in Common-Pool Resource Management." Universidade de São Paulo. https://teses.usp.br/teses/disponiveis/12/12139/tde-13122017- 171553/ publico/CorrigidaMatheus.pdf.

2017b. "What Happens When Transaction Costs Go down? Evidence from Return Boxes." Universidade de São Paulo (USP). São Paulo.

. 2018. "Every Book You Take: Evaluating Compliance Behavior in an Information Commons." Universidade de São Paulo (USP). São Paulo.

Albergaria, Matheus, and Maria Sylvia Saes. 2018. "Measuring Externalities in an Information Commons: The Case of Libraries.” Journal of Cleaner Production 192 (10): 855-63. https://doi.org/10.1016/j.jclepro.2018.04.267.

Alesina, Alberto, and Paola Giuliano. 2015. "Culture and Institutions.” Journal of Economic Literature 53 (4): 898-944. https://doi.org/10.1257/jel.53.4.898.

Andreoni, James. 1988. "Why Free Ride? Strategies and Learning in Public Goods Experiments." Journal of Public Economics 37 (3): 291-304. https://doi.org/10.1016/0047-2727(88)90043-6.

Andreoni, James, and Rachel Croson. 2008. "Partners versus Strangers: Random Rematching in Public Goods Experiments." Handbook of Experimental Economics Results 1 (C): 776-83. https://doi.org/10.1016/S15740722(07)00082-0.

Angrist, Joshua D, and Jörn-Steffen Pischke. 2009. Mostly Harmless Econometrics: An Empiricist's Companion. Princeton: Princeton University. 
Apesteguia, Jose, Patricia Funk, and Nagore Iriberri. 2013. "Promoting Rule Compliance in Daily-Life: Evidence from a Randomized Field Experiment in the Public Libraries of Barcelona." European Economic Review 64 (2): 266-84. https://doi.org/10.1016/j.euroecorev.2013.08.010.

Arıkan, Andaç T. 2018. "Opportunism Is in the Eye of the Beholder: Antecedents of Subjective Opportunism Judgments." Journal of Business Ethics, no. 0123456789. https://doi.org/10.1007/s10551-018-3873-7.

Bandiera, Oriana, Iwan Barankay, and Imran Rasul. 2011. "Field Experiments with Firms." Journal of Economic Perspectives 25 (3): 63-82. https://doi.org/10.1257/jep.25.3.63.

Bar-Ilan, Avner, and Bruce Sacerdote. 2004. "The Response of Criminals and Noncriminals to Fines." Journal of Law and Economics 47 (1): 1-17. https://doi.org/10.1017/CBO9781107415324.004.

Barber, Brad M, and Terrance Odean. 2008. "All That Glitters: The Effect of Attention and News on the Buying Behavior of Individual and Institutional Investors.” Review of Financial Studies 21 (2): 785-818. https://doi. org/10.1002/9781118467411.ch7.

Bauman, Yoram, and Elaina Rose. 2011. "Selection or Indoctrination: Why Do Economics Students Donate Less than the Rest?" Journal of Economic Behavior and Organization 79 (3): 318-27. https://doi.org/10.1016/j. jebo.2011.02.010.

Beach, Brian, and Daniel B Jones. 2016. "Business as Usual: Politicians with Business Experience, Government Finances, and Policy Outcomes." Journal of Economic Behavior and Organization 131 (1): 292-307. https:// doi.org/10.1016/j.jebo.2016.09.010.

Becker, Gary S. 1968. "Crime and Punishment: An Economic Approach.” Journal of Political Economy 76 (2): 169-217. https://doi.org/https://doi.org/10.1086/259394.

Becker, Sascha O, and Andrea Ichino. 2002. "Estimation of Average Treatment Effects Based on Propensity Scores.” The Stata Journal 2 (4): 358-77. https://doi.org/The Stata Journal.

Bénabou, Roland, and Jean Tirole. 2011. "Laws and Norms." 17579. NBER Working Paper Series. Cambridge.

Benjamin, Daniel J, James J Choi, and Geoffrey W Fisher. 2016. "Religious Identity and Economic Behavior." Review of Economics and Statistics 98 (4): 617-37. https://doi.org/https://doi.org/10.1162/REST_a_00586.

Blevins, D P, E W K Tsang, and S M Spain. 2015. "Count-Based Research in Management: Suggestions for Improvement.” Organizational Research Methods 18 (1): 47-69. https://doi.org/10.1177/1094428114549601.

Bollier, David. 2007. "The Growth of the Commons Paradigm." In Understanding Knowledge as a Commons: From Theory to Practice, 27-40. Cambridge: MIT Press.

Cadsby, Charles Bram, and Elizabeth Maynes. 1998. "Choosing between a Socially Efficient and Free-Riding Equilibrium: Nurses versus Economics and Business Students.” Journal of Economic Behavior \& Organization 37 (2): 183-92. https://doi.org/10.1016/S0167-2681(98)00083-3.

Cameron, A Colin, and Pravin K Trivedi. 1990. "Regression Based Tests for Overdispersion in the Poisson Model." Journal of Econometrics 46 (3): 347-64.

. 2009. Microeconometrics Using Stata. Stata Press Books. Vol. 5. https://doi.org/10.1016/S03044076(00)00050-6.

Cárdenas, Juan Camilo. 2003. "Real Wealth and Experimental Cooperation: Experiments in the Field Lab." Journal of Development Economics 70 (2): 263-89. https://doi.org/10.1016/S0304-3878(02)00098-6.

Cárdenas, Juan Camilo, and Elinor Ostrom. 2004. "What Do People Bring into the Game? Experiments in the Field about Cooperation in the Commons." Agricultural Systems 82 (3): 307-26. https://doi.org/10.1016/j. agsy.2004.07.008.

Cárdenas, Juan Camilo, and Pablo Andrés Ramos. 2006. Manual de juegos económicos para el análisis del uso colectivo de los recursos naturales.

Carnicelli, Lauro, and Fernando Postali. 2012. "Rendas do petróleo e tributos locais: uma análise de propensity score." In Encontro Nacional da Associação Nacional dos Centros de Pós-Graduação em Economia (ANPEC), 1-18. https://doi.org/10.2139/ssrn.2109577. 
Carter, John R, and Michael D Irons. 1991. “Are Economists Different, and If so, Why?”Journal of Economic Perspectives 5 (2): 171-77. https://doi.org/10.1257/jep.5.2.171.

Chalfin, Aaron, and Justin McCrary. 2017. "Criminal Deterrence: A Review of the Literature." Journal of Economic Literature 55 (1): 5-48. https://doi.org/10.1257/aer.101.5.2157.

Chaudhuri, Ananish. 2011. "Sustaining Cooperation in Laboratory Public Goods Experiments: A Selective Survey of the Literature." Experimental Economics 14 (1): 47-83. https://doi.org/10.1007/s10683-010-9257-1.

Chetty, Raj, Emmanuel Saez, and László Sándor. 2014. "What Policies Increase Prosocial Behavior? An Experiment with Referees at the Journal of Public Economics." Journal of Economic Perspectives 28 (3): 169-88. https://doi.org/10.1257/jep.28.3.169.

Dawes, Robyn M, and Richard H Thaler. 1988. “Anomalies: Cooperation.” Journal of Economic Perspectives 2 (3): 187-97. https://doi.org/10.1257/jep.2.3.187.

Dehejia, Rajeev H, and Sadek Wahba. 2002. "Propensity Score-Matching Methods for Nonexperimental Causal Studies." Review of Economics and Statistics 84 (1) (1): 151-61. https://doi.org/10.1162/003465302317331982.

Delis, Manthos D, Iftekhar Hasan, and Maria Iosifidi. 2019. "On the Effect of Business and Economic University Education on Political Ideology: An Empirical Note.” Journal of Business Ethics 155 (3): 809-22. https://doi. org/10.1007/s10551-017-3483-9.

DellaVigna, Stefano, and Joshua Matthew Pollet. 2009. "Investor Inattention and Friday Earnings Announcements.” Journal of Finance 44 (2): 709-49. https://doi.org/10.2139/ssrn.843786.

Demsetz, Harold. 1967. "Toward a Theory of Property Rights." American Economic Review (Papers and Proceedings) 57 (2): 347-59.

Desmarais, Bruce A, and Jeffrey J Harden. 2013. "Testing for Zero Inflation in Count Models: Bias Correction for the Vuong Test.” The Stata Journal 13 (4): 810-35.

Dietz, Thomas, Elinor Ostrom, and Paul C Stern. 2003. "The Struggle to Govern the Commons." Science 302 (5652): 1907-12. https://doi.org/10.1126/science.1091015.

Falk, Armin, and James J Heckman. 2009. "Lab Experiments Are a Major Source of Knowledge in the Social Sciences." Science 326 (5952): 535-39.

Fehr, Ernst, and Simon Gächter. 2000. "Cooperation and Punishment in Public Goods Experiments." American Economic Review 90 (4): 980-94. https://doi.org/10.1126/science.151.3712.867-a.

Fehr, Ernst, and Andreas Leibbrandt. 2011. "A Field Study on Cooperativeness and Impatience in the Tragedy of the Commons." Journal of Public Economics 95 (9): 1144-55. https://doi.org/http://dx.doi.org/10.1016/j. jpubeco.2011.05.013.

Fisman, Raymond, and Edward Miguel. 2007. "Corruption, Norms, and Legal Enforcement: Evidence from Diplomatic Parking Tickets." Journal of Political Economy 115 (6): 1020-48. https://doi.org/10.1086/527495.

Fosgaard, Mia Reinholt, Toke Reinholt Fosgaard, and Nicolai J Foss. 2017. "Consumer or Citizen? Prosocial Behaviors in Markets and Non-Markets." Social Choice and Welfare, forthcoming: 1-23.

Frank, Robert H, Thomas Gilovich, and Dennis T Regan. 1993. "Does Studying Economics Inhibit Cooperation?" Journal of Economic Perspectives 7 (2): 159-71. https://doi.org/10.1257/jep.7.2.159.

Fréchette, Guillaume. 2015. "Laboratory Experiments: Professionals versus Students.” In Handbook of Experimental Economic Methodology, ed. Guillaume Fréchette and Andrew Schotter, 360-90. New York: Oxford University.

Frey, Bruno S, and Stephan Meier. 2003. "Are Political Economists Selfish and Indoctrinated? Evidence from a Natural Experiment.” Economic Inquiry 41 (3): 448- 62. https://doi.org/10.1093/ei/cbg020.

. 2004. "Pro-Social Behavior in a Natural Setting." Journal of Economic Behavior and Organization 54 (1): 65-88. https://doi.org/10.1016/j.jebo.2003.10.001.

2005. "Selfish and Indoctrinated Economists?" European Journal of Law and Economics 19 (2): 165-71. https://doi.org/10.1007/s10657-005-5425-8. 
Gabaix, Xavier. 2019. “Behavioral Inattention.” In Handbook of Behavioral Economics, ed. B. Douglas Bernheim, Stefano DellaVigna, and David I. Laibson, 261-343. Handbook of Behavioral Economics - Foundations and Applications 2. Cambridge: Elsevier. https://doi.org/10.3386/w24096.

Galiani, Sebastian, Paul Gertler, and Ernesto Schargrodsky. 2005. "Water for Life: The Impact of the Privatization of Water Services on Child Mortality." Journal of Political Economy 113 (1): 83-120. http://www.jstor. org/stable/10.1086/426041.

Getz, Malcolm. 1989. “The Economics of Research Libraries: Present State and FutureProspects." IFLA Journal 15 (4): 299-305.

Gneezy, Uri, Andreas Leibbrandt, and John List. 2016. "Ode to the Sea: Workplace Organizations and Norms of Cooperation.” Economic Journal 126 (595): 1856-83. https://doi.org/10.1111/ecoj.12209.

Gneezy, Uri, Stephan Meier, and Pedro Rey-Biel. 2011. "When and Why Incentives (Don't) Work to Modify Behavior.” Journal of Economic Perspectives 25 (4): 1-21. https://doi.org/10.1257/jep.25.4.191.

Gneezy, Uri, and Aldo Rustichini. 2000a. “A Fine Is a Price.” Journal of Legal Studies 29 (1): 1-17. https://doi. org/10.1086/468061.

\section{.2000b. “Pay Enough or Don’t Pay at All.” Quarterly Journal of Economics 115 (3): 791-810.}

Godos-Díez, J L, R Fernández-Gago, and L Cabeza-García. 2015. "Business Education and Idealism as Determinants of Stakeholder Orientation." Journal of Business Ethics 131 (4): 439-52. https://doi.org/10.1007/ s10551-014-2289-2.

Goeree, Jacob K, Margaret A McConnell, and Tiffany Mitchell. 2010. "The 1/d Law of Giving." American Economic Journal: Microeconomics 2 (1): 183-203. https://doi.org/10.1257/mic.2.1.183.

Guimarães, Paulo, and Pedro Portugal. 2010. “A Simple Feasible Procedure to Fit Models with High-Dimensional Fixed Effects.” Stata Journal 10 (4): 628-49. https://doi.org/10.1177/1536867x1101000406.

Hardin, Garrett. 1968. "The Tragedy of the Commons." Science 162 (3859): 1243-48.

Haselhuhn, Michael P, Devin G Pope, Maurice E Schweitzer, and Peter Fishman. 2012. "The Impact of Personal Experience on Behavior: Evidence from Video-Rental Fines.” Management Science 58 (1): 52-61. https://doi. org $/ 10.1287 / \mathrm{mnsc} .1110 .1367$.

Henrich, Joseph, Robert Boyd, Samuel Bowles, Colin Camerer, Ernst Fehr, Herbert Gintis, and Richard McElreath. 2001. "In Search of Homo Economicus: Behavioral Experiments in 15 Small-Scale Societies." American Economic Review 91 (2): 73-84. https://doi.org/10.1257/aer.91.2.73.

Hess, Charlotte, and Elinor Ostrom. 2007a. "Introduction: An Overview of the Knowledge Commons." In Understanding Knowledge as a Commons: From Theory to Practice, ed. Charlotte Hess and Elinor Ostrom, 3-26. Boston: MIT Press.

- 2007b. Understanding Knowledge as a Commons. Ed. Charlotte Hess and Elinor Ostrom. Cambridge: MIT Press.

Hirshleifer, David, Sonya Seongyeon Lim, and Siew Hong Teoh. 2009. "Driven to Distraction: Extraneous Events and Underreaction to Earnings News." Journal of Finance 64 (5): 2289-2325. https://doi.org/10.1111/j.15406261.2009.01501.x.

Huck, Steffen, and Imran Rasul. 2010. "Transactions Costs in Charitable Giving: Evidence from Two Field Experiments.” The BE Journal of Economic Analysis \& Policy 10 (1): 31. https://doi.org/10.2202/1935-1682.2494.

Kagel, John H. 2009. "Laboratory Experiments." In The Methods of Modern Experimental Economics, ed. Guillaume Fréchette and Andrew Schotter. Oxford: Oxford University.

Kamenica, Emir. 2012. "Behavioral Economics and Psychology of Incentives." Annual Review of Economics 4 (1): 13.1-13.26. https://doi.org/10.1146/annurev-economics-080511-110909.

Koechlin, Carol. 2010. "Leading the Way in the Learning Commons." Teaching Librarian

17 (2): 20-23.

Estud. Econ., São Paulo, vol.51 n.4, p.643-675, out.-dez. 2021 
Ledyard, J O. 1995. "Public Goods: A Survey in Experimental Research.” In Handbook of Experimental Economics, ed. John H. Kagel and Alvin Roth, 111-94. Princeton: Princeton University.

Levitt, Steven D, and Thomas J Miles. 2006. "Economic Contributions to the Understanding of Crime." Annual Review of Law and Social Science 2 (1): 147-64. https://doi.org/10.1146/annurev.lawsocsci.2.081805.105856.

Li, Mingxiang. 2012. "Using the Propensity Score Method to Estimate Causal Effects: A Review and Practical Guide." Organizational Research Methods 16 (2): 188-226. https://doi.org/10.1177/1094428112447816.

List, John. 2011. "Why Economists Should Conduct Field Experiments and 14 Tips for Pulling One Off." Journal of Economic Perspectives 25 (3): 3-16. https://doi.org/10.1257/jep.25.3.3.

Long, J Scott, and Jeremy Freese. 2001. "Predicted Probabilities for Count Models.” The Stata Journal 1 (1): 51-57.

Marwell, Gerald, and Ruth E Ames. 1981. "Economists Free Ride, Does Anyone Else?” Journal of Public Economics 15 (3): 295-310. https://doi.org/10.1016/0047- 2727(81)90013-X.

Masclet, David, Charles Noussair, Steven Tucker, and Marie Claire Villeval. 2003. "Monetary and Nonmonetary Punishment in the Voluntary Contributions Mechanism." American Economic Review 93 (1): 366-80. https:// doi.org/10.1257/000282803321455359.

Meier, Stephan, and Bruno S Frey. 2004. "Do Business Students Make Good Citizens?” International Journal of the Economics of Business 11 (2): 141-63. https://doi.org/10.1080/1357151042000222492.

Melé, Domènec. 2009. "Integrating Personalism into Virtue-Based Business Ethics: The Personalist and the Common Good Principles." Journal of Business Ethics 88: 227-44. https://doi.org/10.1007/s10551-009-0108-y.

Olson, Mancur. 1965. The Logic of Collective Action: Public Goods and the Theory of Groups. Cambridge: Harvard University.

Ostrom, Elinor. 1990. Governing the Commons: The Evolution of Institutions for Collective Action. New York: Cambridge University. https://doi.org/10.1017/CBO9780511807763.

. 1999. "Coping with Tragedies of the Commons." Annual Review of Political Science 2 (1): 493-535. https://doi.org/10.1146/annurev.polisci.2.1.493.

- 2000. "Collective Action and the Evolution of Social Norms." Journal of Economic Perspectives 14 (3): 137-58. https://doi.org/10.1257/jep.14.3.137.

_. 2005. Understanding Institutional Diversity. Princeton: Princeton University. https://doi.org/10.1007/ s11127-007-9157-x.

_ 2007. "Developing a Method for Analyzing Institutional Change." 07-1. Workshop in Political Theory and Policy Analysis.

2010. "Beyond Markets and States: Polycentric Governance of Complex Economic Systems." American Economic Review 100 (3): 641-72. https://doi.org/10.1257/aer.100.3.1.

Paloheimo, Harri, Michael Lettenmeier, and Heikki Waris. 2015. "Transport Reduction by Crowdsourced Deliveries - a Library Case in Finland.” Journal of Cleaner Production 132 (20): 240-51. https://doi.org/10.1016/j. jclepro.2015.04.103.

Perc, Matjaž, Jillian J Jordan, David G Rand, Zhen Wang, Stefano Boccaletti, and Attila Szolnoki. 2017. "Statistical Physics of Human Cooperation." Physics Reports 687 (1): 1-51. https://doi.org/10.1016/j.physrep.2017.05.004.

Piehl, Anne Morrison, and Geoffrey Williams. 2011. "Institutional Requirements for Effective Imposition of Fines.” In Controlling Crime: Strategies and Tradeoffs, ed. Philip J. Cook, Lens Ludwig, and Justin McCrary, 95-121. Chicago: University of Chicago.

Polinsky, A Mitchell, and Steven Shavell. 2000. “The Economic Theory of Public Enforcement of Law.” Journal of Economic Literature 38 (1): 45-76. https://doi.org/10.1257/jel.38.1.45.

Rosen, C Martin, and Gabrielle M Carr. 1997. "Fares and Free Riders on the Information Highway." Journal of Business Ethics 16: 1439-45.

Rubinstein, Ariel. 2006. “A Sceptic's Comment on the Study of Economics.” Economic Journal 116 (510): C1-9. https://doi.org/10.1111/j.1468-0297.2006.01071.x. 
Ruske, René. 2015. "Does Economics Make Politicians Corrupt? Empirical Evidence from the United States Congress.” Kyklos 68 (2): 240-54. https://doi.org/https://doi.org/10.1111/kykl.12082.

Rustagi, Devesh, Stefanie Engel, and Michael Kosfeld. 2010. "Conditional Cooperation and Costly Monitoring Explain Success in Forest Commons Management.” Science330 (6006): 961-65. https://doi.org/10.1126/ science.1193649.

Simon, Herbert A. 1955. “A Behavioral Model of Rational Choice.” Quarterly Journal of Economics LXIX (1): 99-118. https://doi.org/10.2307/1884852.

Smith, Vernon L. 1989. “Theory, Experiment and Economics.” Journal of Economic Perspectives 3 (1): 151-69. https://doi.org/10.1257/jep.3.1.151.

Stigler, George J. 1974. "The Optimum Enforcement of Laws." In Essays in the Economics of Crime and Punishment, ed. Gary S. Becker and William M. Landes, I:55-67. New York: National Bureau of Economic Research (NBER). https://doi.org/10.1086/259646.

Surprenant, Chris W. 2017. "Policing and Punishment for Profit." Journal of Business "Ethics, forthcoming. https://doi.org/10.1007/s10551-017-3744-7.

Trivedi, Pravin K. 2010. "Recent Developments in Panel Models for Count Data.” Mexico: Mexican Stata Users Group Meeting.

Vollan, B, and Elinor Ostrom. 2010. "Cooperation and the Commons." Science 330 (6006): 923-24. https://doi. org/10.1126/science.1197881.

Vuong, Quang H. 1989. "Likelihood Ratio Tests for Model Selection and Non-Nested Hypotheses." Econometrica 57 (2): 307-33.

Yezer, Anthony M, Robert S Goldfarb, and Paul J Poppen. 1996. "Does Studying Economics Discourage Cooperation? Watch What We Do, Not What We Say or How We Play." Journal of Economic Perspectives 10 (1): 177-86. https://doi.org/10.1257/jep.10.1.177.

Zelmer, Jennifer. 2003. "Linear Public Goods Experiments: A Meta-Analysis.” Experimental Economics 6 (2): 299-310. https://doi.org/https://doi.org/10.1023/A:102627742. 